\title{
Soft power's next steppe: National Projection at the Astana EXPO 2017
}

\author{
Nicholas J. Cull ${ }^{1}$
}

(C) Macmillan Publishers Ltd 2017

The application of soft power, nation branding, and public diplomacy are at their heart competitive and it is only to be expected that our field pays close attention to opportunities to see the great players compared. The summer of 2017 brought a first rate snap shot of the state of play in the form of the latest iteration of Portland's Soft Power 30: the headline was France stepping into the top spot ahead of the UK and USA. France's strength and America's comparative weakness included leadership on the issue of climate change. ${ }^{1}$ Yet it is equally interesting to see the great nations-or their proxies—set out physically side by side. For that experience, it was necessary to head to the steppes of Central Asia, where the Kazakhstan was hosting an international expo in its recently built capital Astana. The expo theme was 'future energy.'

The Astana expo was one of the smaller 'specialized' class of expos, like Yeosu, Korea 2012; Zaragosa, Spain, 2008; or Aichi, Japan, 2005, rather than a full world expo like Milan, 2015; Shanghai, 2010; or Hanover, 2000. ${ }^{2}$ This meant that only Kazakhstan had a free standing national pavilion of its own: a spectacular eight story glass sphere at the center of the sight. Other nations took space in a gleaming arc of buildings around the circumference of the site. They marked their presence with giant banners on the shared wall and decorated the pavilion entrances with considerable complexity. The lower status of the expo meant that some expo regulars opted to stay away and many small countries took booths in regional halls. This said, around fifty countries opted to create multi-room exhibits in national pavilion spaces. These pavilions

Nicholas J. Cull

cull@usc.edu

University of Southern California, Los Angeles, USA provide a fascinating window on the current state of national self-representation.

The show's theme meant that the content of many pavilions overlapped. After a few hours at the expo, the tag lines seemed to merge. There were many takes on the idea of collaboration, which the UAE articulated as 'the energy we create together.' There was a 'Land of Energy' (Azerbaijan), a 'Center of Energy' (Turkey), and 'Land of Light: Energy for All' (Algeria). Many exhibits presented variations of the same idea: upgraded solar panels were ubiquitous; windmills and waterwheels spun; cross sections of biomass furnaces winked in every corner and ingenious, wave energy devices abounded: there was an entire gallery of competing wave energy designs in the Kazakh pavilion; solar aircraft featured in the UAE, South Korea, Czech, and Slovak pavilions, while 'infinity mirrors' were part of Germany, Israel, and Spain. The boldest idea-seen in the Kazakh and Chinese pavilions-was for a space-based solar energy collector which will zap beams of power down to earth. Not all the slogans were credible: is Pakistan really 'magnificent, resplendent' to anyone but its own citizens? Similarly not all overlapping ideas were created equal: the best-looking solar concept car was in the French Pavilion, where the Peugeot pipped Germany's BMW. The best journey-to-a-future-city film was in the Chinese pavilion, where a magical phoenix showed a cave-girl the future of civilization before resurrecting her frozen super model mother.

\footnotetext{
${ }^{1} \mathrm{http} / / /$ softpower30.portland-communications.com/wp-content/uploads/ 2017/07/The-Soft-Power-30-Report-2017-Web-1.pdf.

${ }^{2}$ For American comparisons, Seattle 1962 was a world expo but Spokane 1974 and Knoxville 1982 and New Orleans 1984 were specialized expos.
} 
Some countries broke from the pack: Austria, Britain, and Japan did best. Austria, which had a good story to tell about the country's use of renewable energy, decided to relegate the text to the edge and rather to focus on building an association between their country and fun by building their entire pavilion around brightly colored human-powered contraptions that variously honked, squeaked, and lit up when visitors pedaled, pulled, or pushed. As at Shanghai and Milan, Britain built its Astana pavilion around a single concept; the UK's offering focused on technology made possible by the super-material known as graphene, for which a University of Manchester team won a Nobel Prize in 2010. The architect Asif Khan used the material to create an amazing installation. At the center was the skeleton of a traditional Kazakh yurt build out of graphene rods. These rods glowed when touched by visitors, not only illuminating the interior but also changing the weather in a $60-\mathrm{m}$ computer-generated frieze of Scottish-type highlands. The more touches, the better the weather. If only the real British weather were as malleable. Japan in contrast built its pavilion around the idea of dancing, noting that dance and celebration were central to both Kazakh and Japanese culture. It had one hall in which a video wall introduced some typical regional dances and a second hall in which the dancers were first magically multiplied by CGI, then joined by actual dancers who left their stage and invited Kazakhs to join in, all while CGI transplanted audience faces onto the bodies of Japanese dancers on the screen. It was quirky, oddly hypnotic, memorable, and the local audience loved it.

Unlike the Japanese, many countries decided not to import their own performers or pavilion crews and recruited locally. Multi-lingual students from the nearby campus of Nazarbayev University did a terrific job, but there is nothing quite like an encounter with a citizen from the country being depicted. Sri Lanka, Vietnam, and India had craftsmen; the Gulf States had guides resplendent in traditional costume; Thailand had a puppeteer; many of the African countries had hosts at their booths (favorite targets for selfie-obsessed locals), but the undoubted winner in the guide stakes was the United States. As at the famed expos of the Cold War, the US fielded an engaging corps of students to mingle with the fair-goers and answer questions about everyday life in America. Given the limited availability of Kazakh-speaking Americans, they used Russian as their Lingua Franca. The US pavilion itself was built around an up-beat film evoking American vitality and diversity, arguing that the people were the great source of US energy. It neatly dodged knotty issues like this past spring's US withdrawal from the Paris Climate Accord. Besides the guides, the big crowd pleaser in the US pavilion was a cardboard Hollywood sign for selfies, which was part of a social media-based competition. The pavilion showed that it is often tiny low-cost details at pavilions which resonate with audiences. While some guests were puzzled that the pavilion was not as lavish as those of Russia, Germany, France, or China, they plainly had no idea quite what a miracle it was that the US had mustered the resources to attend at all and how well limited means had been stretched to deliver a solid contribution.

Next only to personal contact, gastro diplomacy is the great mainstay of expos. India, Thailand, Korea, Vietnam, Germany, the Czech Republic, and others too all brought food to the fair. The best restaurant that I tried was at the Polish pavilion. In fact the entire Polish pavilion was very well mounted. In contrast to the lackluster Polish showing in Milan (built around a clunky animated history of Poland), the country's 2017 show was engaging and tightly focused on the energy theme. It gave special emphasis on clean ways to use the country's coal supply. The upgraded Polish presence was doubtless related to the candidacy of the Polish city of Łódź to host a specialized expo in 2022. Most restaurants were on a floor above the actual pavilion, but one or two tried to integrate food into their exhibit. The Swiss pavilion included a cookery demonstration: locally recruited chefs made potato rosti in a mock-up Swiss chalet and quizzed the audience about ways to reduce their carbon foot-print of the kitchen. It made an engaging highlight to a nicely designed if text-heavy pavilion.

Some pavilions were angled to promote tourism and looked for ways to show their scenery rather than their technology. Most of the small-country stalls were tourismfocused. On the pavilions, Greece created a terrace and bar to enable visitors to look as if they were in the Aegean. Jordan built a replica of the iconic entrance into Petra as the gateway to its pavilion. Some countries looked to technology. The best virtual reality tour was in Georgia, which like Latvia and Lithuania and some others had headsets to provide three-dimensional encounters with spectacular countryside. Georgia's headsets worked and the views were truly spectacular. The best conventional movie wall was in the Slovakian pavilion, which also had amazing views to share. Landscape alternated with a short video called Follow me to Slovakia in which the filmmaker Patrik Paulinyi intercuts multiple Go-Pro back views of the same young woman leading him by the hand through ninety or so spectacular land and cityscapes in the country. ${ }^{3}$ The high-definition video wall was created by a Slovak company called Kvant and so did double duty. The Slovaks also managed to include a laser installation, a wall dedicated to Slovak science pioneers and an amazing selfcontained solar-powered camping pod. It was all branded around the idea that Slovakia was a 'good idea' and went to

\footnotetext{
3 The film may be viewed here https://www.youtube.com/watch?v= fbkEmW6PIXs.
} 
make probably the best of the small-country offerings at the expo.

It is rule of expos that up-coming hosts and candidate countries put on good shows. Confirmed host UAE did a creditable pavilion, with an engaging preview of Dubai 2020 at the end. The contenders for the specialized expo in 2022/3 brought even more energy to the fight. Łódź and Minneapolis were well represented by their national spaces and, as home to candidate city Buenos Aires, Argentina was the only Latin American country to mount a full pavilion. The fourth contender for 2022-Rio de Janeiropresumably forfeited its chances when Brazil pulled out of Astana. The decision will be made in November 2017. Of the candidates for the next full expo-2025-the home nations of Paris, Osaka, Baku, and Ekaterinburg all ensured their offerings at Astana did not disappoint. The 2025 decision is scheduled to be announced in November 2018.

Of course not every pavilion hit its mark. Some offerings seemed dull. Italy and Spain-stars of past exposfailed to catch fire and neither Hungary nor Romania added much. The Gulf States were insufficiently differentiated. Luxembourg was forgettable and Serbia had some strong design elements but dropped the ball by including an odd animated film about Serb-born tech pioneer Nikola Tesla in which he rides through New York City in a carriage powered by a piano. ${ }^{4}$ Some nations let slip an unfortunate sense of superiority over Kazakhstan. The Dutch ('Low Land/High Energy') asked Kazakh's to 'share the mindset' and led off with a holographic show which displayed key examples of Netherlands technology through the ages as if they were summoned by magic. The show obscured an admirable bilateral collaborative project associated with the pavilion to bring together young Kazakh's and Dutch design students to create projects together. One would not have known from the pavilion that $40 \%$ of this year's inward investment in Kazakhstan originated in the Netherlands. ${ }^{5}$ The Korean pavilion was dramatic and pulled crowds in for a show during which the animated hero and heroine stepped through the screen to be represented by real dancers. The content of the show was somewhat condescending-a romance between a Korean girl and a Kazakh pilot who runs out of fuel and crash lands on a future version of Korea's Jeju Island full of robots, solar power, and high tech. The girl steals the boy's diesel gas can and tries to show him a better way. The Kazakhs enjoyed the dancing but disliked the implication that they were quite so backward. The loudest complaints which I heard while chatting with fair-goers related to the pavilions

\footnotetext{
${ }^{4}$ The film was created in 2013 and may be viewed here https://www. youtube.com/watch?v=TElh0VTD5Di.

5 http://lenta.inform.kz/en/netherlands-present-expo-2017-pavilion_ a3026887.
}

put up by countries with well-publicized problems such as Israel and Venezuela. I was told it was dishonest that Israel made no mention of its political troubles. While changing the narrative had worked well in the past three expos-it may be that the 'energy of creation' line was too glib for a country with its own eye on the region and its own place in the Islamic Umma. Iran's pavilion also fell flat. While it included a beautiful video wall which at some points displayed a dozen or so Iranian women musicians playing, embedded in glorious carpet-like patterns, it hopelessly over-estimated the attention span of its audience. The pavilion took $50 \mathrm{~min}$ to cycle through all of the video offerings being show. Most Kazaks came in only to get a stamp for their souvenir expo passport..

Every expo throws up its quirks. Shanghai had its robot baby; Milan had its giant figures built out of food. Memorable images in Astana included the whale flying over a city in the Monaco pavilion, the garbage built into the floor of the Vatican pavilion, or the wall of tiny holographic dervishes dancing at the exit to a Turkish pavilion, which had otherwise focused only on Turkish science and technology. The surprise hit of the fair was one element of the Thai pavilion: a model of the rear end of an elephant and an illuminated example of a giant piece of waste which had just been expelled from the same. In context it was an example of how agricultural bi-products could yield energy logic was lost next to opportunity to be photographed with a giant, glowing piece of pachyderm poop. Other favorites with visitors included the giant iceberg in the Russian pavilion, though aficionados will note that Moscow was here channeling the glacier ice core featured in the awardwinning Swiss pavilion at Yeosu in 2012. No one minded the homage as the temperature outside rose.

Of course any encounter with an expo throws up examples of significant absences. In Astana as at Milan, a number of traditional stalwart expo countries stayed away including Australia, and Canada, which had at one point spoken of hosting the 2017 expo in Edmonton as part of its national bicentennial. Belgium was in Milan and had formally bid for a 2017 show in Liege but opted not to come. The expo map bizarrely promised a Wallonia exhibit in the Caribbean hall, but I could not find it. As at Milan, all the Scandinavians stayed home, though their Nordic neighbor Finland showed up. New Zealand stayed home again and Brazil, whose fortunes have declined since its positive showing in Milan cancelled at the last minute. There were also fascinating absences of content. The world of 2017 is often overshadowed by strong-man politics. I expected to see this reflected in pavilions with messages from the likes of Russia's Putin, Turkey's Erdogan, or even America's Trump. This was not the case. There was little indication of cults of personality anywhere in the grounds, even in the pavilion of Kazakhstan, a country where its long-term 
president-Nursultan Nazarbayev-has a centrality in political and intellectual life which surprises western observers. The Thais could not resist interrupting their show based around the adventures of an amiable talking corn ear to note that the late king of Thailand had personally pioneered agricultural development in a quest to solve world food shortages. The only real attempts to project a personal image of power were in the pavilions for Turkmenistan and China. China displayed images of president $\mathrm{Xi}$ and quotes reflecting his vision of renewable energy and a 'green silk road' throughout its pavilion.

Every expo host hopes that the show will reflect credit on the organizers. It was not immediately clear that the massive investment in Astana had paid off. Certainly, the Kazakh pavilion was a triumph and a worthy addition to the list of iconic structures created for expos such as the Eiffel tower, Brussels Atomium, Seattle space needle, and Shanghai Crown of Asia. But while there was a level of kudos in simply bidding for, winning, and hosting such an event, it was an open secret on the fairground that few foreigners had flown into visit and that local attendance had been disappointing. Some experiences of exhibitors were unflattering. Pavilion teams muttered darkly about import restrictions and unnecessary bureaucracy, about problems obtaining documents like licenses to serve alcohol in restaurants or getting products to sell in retail space in time. Empty stalls told their own story. There was also a rumor that some local attendees at the fair had been bussed in without much in the way of consent. This said, the glass was more than half full. Kazakhstan showed the world that it is a friendly and hospitable country, well able to manage a mega event. With regard to the domestic audience, the expo plainly played a role in Kazakhstan's wider strategy of preparing its population for a global future: bringing the world to Astana, and giving locals a direct look at what that world has to offer. Other developments like adopting the Roman alphabet as the country's script in place of Cyrillic or the shift to English as the language of instruction in STEM teaching from middle school onwards play to this same goal. Finally, the ultimate text of an expo is in its ability to transform the site into a valuable resource after the exhibition has closed. This has been the Achilles heel of the otherwise unmatchable Shanghai show of 2010. The
Astana expo was planned with a clear end state in mind. The expo grounds will become a special trade park which will operate under UK investment rules.

At the end of the day then who 'won' the expo? For my part at least, there is a correlation between the top end of Portland's Soft Power 30 and my own reactions to offerings in Astana. Britain and Germany were on form but France was ahead of them both. There was something special about the French offering in Astana. Its design reflected a blend of corporate innovation and engaging heritage. It avoided the heavy emphasis on text that plagues German pavilions, but hit more buttons than recent British offerings. It was stylish enough to appeal to any person of taste, but knowledgeable enough about the people of Kazakhstan to know, for example, that an early nod to the locally beloved writer Antoine de Saint-Exupéry and his Little Prince would resonate well. Great pavilions always begin with great research. But expos should be about more than just national promotion. The celebrated expos of the past-Paris, 1878; New York, 1939; Montreal, 1967-have reminded visitors of the possibility inherent in humanity and have brought visions of a better life. Such visions of the future are sorely needed in a world which has spent too much time in recent years fixating on idealized visions of the past, and as a result planning to make countries great again, build walls, and generally withdraw from collective effort. France not only displayed building blocks of a better future, but it also reminded visitors that the original visionary of the future was its own Jules Verne. The French pavilion included a photograph of Verne with swirling dayglow highlights. If the remarkable technologies for future energy generation and conservation promised by the exhibitors can be brought on-line, the whole planet will be winners. No wonder the portrait of Jules Verne seemed to be smiling.

Nicholas J. Cull is professor of Public Diplomacy at the University of Southern California. He is co-editor of this journal and author of many books and articles dealing with the intersection of culture, media and foreign policy, most especially from a historical perspective. His books include The Decline and Fall of the United States Information Agency: American public diplomacy, 1989-2001, Palgrave, 2012. 